\title{
Correction to: Update on human genetic susceptibility to COVID-19: susceptibility to virus and response
}

Vito Luigi Colona ${ }^{1}$, Vasilis Vasiliou ${ }^{2}$, Jessica Watt ${ }^{3}$, Giuseppe Novelli ${ }^{1,4,5}$ and Juergen K. V. Reichardt ${ }^{*}$

\section{Correction to: Hum Genomics (2021) 15:57} https://doi.org/10.1186/s40246-021-00356-x

Following publication of the original article [1], the authors identified an error in the family name of the second author Vasilis Vasiliou.

The incorrect author name is: Vasilis Vasilou.

The correct author names is: Vasilis Vasiliou.

The author group has been updated above and the original article [1] has been corrected.

\section{Author details}

'Department of Biomedicine and Prevention, "Tor Vergata" University of Rome, 00133 Rome, Italy. ${ }^{2}$ Department of Environmental Health Sciences, School of Public Health, Yale University, New Haven, USA. ${ }^{3}$ College of Public Health, Medical and Veterinary Sciences, James Cook University, Smithfeld, QLD, Australia. ${ }^{4}$ IRCCS Neuromed, Pozzilli, IS, Italy. ${ }^{5}$ Department of Pharmacology, School of Medicine, University of Nevada, Reno, NV 89557, USA. ${ }^{6}$ Australian Institute of Tropical Health and Medicine, James Cook University, Smithfeld, QLD 4878, Australia.

Published online: 18 September 2021

\section{Reference}

1. Colona, et al. Hum Genomics. 2021;15:57.

\section{Publisher's Note}

Springer Nature remains neutral with regard to jurisdictional claims in published maps and institutional affiliations. original author(s) and the source, provide a link to the Creative Commons licence, and indicate if changes were made. The images or other third party material in this article are included in the article's Creative Commons licence, unless indicated otherwise in a credit line to the material. If material is not included in the article's Creative Commons licence and your intended use is not permitted by statutory regulation or exceeds the permitted use, you will need to obtain permission directly from the copyright holder. To view a copy of this licence, visit http://creativecommons.org/licenses/by/4.0/. The Creative Commons Public Domain Dedication waiver (http://creativecommons.org/publicdomain/zero/1.0/) applies to the data made available in this article, unless otherwise stated in a credit line to the data. 